\title{
AOR
}

Selected Papers of \#AolR2021:

The 22nd Annual Conference of the

Association of Internet Researchers

Virtual Event / 13-16 Oct 2021

\section{“THE CREATURE ITSELF IS NASTY, BUT NOTHING REALLY COMPARES TO THE BUILDING OF DREAD BEFORE YOU EVER GET TO IT": ONLINE PLAYER AND DEVELOPER COMMENTARY ON FEMALE MONSTROSITY IN VIDEO GAMES}

Sarah Stang

York University

Gender representation in video games has long been a controversial, heated, and fraught topic of discussion within online gaming communities. In game scholarship, analysis of the usually harmful tropes and trends of female representation has resulted in countless studies demonstrating that video games are often a regressive medium in terms of representation, privileging heterosexual white male subjectivities and erasing, marginalizing, or even vilifying anyone outside of that specific demographic (Ivory, 2006; Williams, et al., 2009). Internet research on this topic has also demonstrated that many online gaming communities are hostile to change regarding female representation, often unwilling to consider concerns regarding the issue, and tend to demonstrate exclusionary practices to reinforce the idea that gaming is a male space-a "boy's club" (Consalvo, 2012; Cote, 2020; Jenson \& de Castell, 2013; Kendrick, 2015; Salter \& Blodgett, 2012; Vossen, 2018).

These conversations and scholarly studies tend to focus on the representation of human women, especially as victimized damsels-in-distress, background decorations, trophies/rewards for the male player-character, or "strong female protagonists" that actually portray women in problematic, one-dimensional ways. Considerably less work has been done to analyse the portrayal of villainous and monstrous nonhuman women in games, even though countless science fiction, fantasy, and horror games feature these kinds of characters. Many of these games utilize harmful tropes and design practices related to female villainy and monstrosity, thereby reinforcing misogynistic ideologies. Indeed, the portrayal of woman-as-monster is ancient and found across world mythologies, folklore, literature, and popular culture. Several feminist scholars have unpacked the misogyny inherent in this portrayal-especially regarding female sexuality, reproduction, and old age-in mythology, religion, and technological and scientific discourse (Kristeva, 1982; de Beauvoir, 1949/2011; Braidotti, 2011) and popular culture, especially film (Caputi, 2004; Creed, 1993; Harrington, 2018; Sobchack, 2000).

Suggested Citation (APA): Stang, S. (2021, October). "The reature itself is nasty, but nothing really compares to the building of dread before you ever get to it": Online player and developer commentary on female monstrosity in video games. Paper presented at AoIR 2021: The 22nd Annual Conference of the Association of Internet Researchers. Virtual Event: AolR. Retrieved from http://spir.aoir.org. 
Regardless of the ubiquity of monstrous enemies in video games, few game scholars have addressed the ways that monstrosity is interwoven with representation (Kocurek, 2015; Stang, 2018; Stang, 2019; Stang \& Trammell, 2019). These studies have primarily used textual analysis to demonstrate how monstrosity functions as a tool of oppression-a label used to justify the ultra-violence enacted against certain characters and creatures by the player-character. Because monsters are often loosely veiled proxies for marginalized or minoritized Others, especially women, people of colour, and people with disabilities, the violence the player is forced to commit against these monstrous creatures can be understood as a symbolic re-enactment of the white supremacist, ableist, heteropatriarchal violence committed against real-world groups.

With the understanding that gender representations in games can have deep cultural ramifications, especially as they intersect with representations of race, sexuality, queerness, body size, disability, mental illness, and age, this paper examines online player and developer discourse regarding female-coded monsters from a selection of commercially successful "AAA" video games. The intent of this project is to contribute to ongoing scholarship on monstrosity in games by looking at how developers explain and justify their design processes in online interviews and forum posts and how players/fans articulate their attitudes towards and reception of these monstrous creatures.

The games I will be discussing are three successful and acclaimed fantasy series: The Witcher series, the God of War series, and the Dragon Age series. The monsters under discussion from these series represent some of the worst archetypes of female monstrosity: Succubi, and Sirens-sexualized femme fatale monsters that prey on men; Broodmothers-large, pregnant, maternal monsters designed to evoke reactions of disgust and horror in players; and Hags, Crones, and Fates-elderly-appearing monstrous women that occupy the intersection of ageism and sexism. The sources for online commentary include forums and message boards such as those on GameFAQs, Steam, Reddit, and each game's individual Wiki page; video discussions and interviews found on YouTube, especially those posted by the development studios or publishers themselves; and developer interviews found on gaming journalism websites like Polygon and Kotaku.

This online commentary reveals that many developers approach the design of female monstrosity either by drawing on existing creatures and tropes found in mythology and popular culture or with the explicit intention of designing monstrous female bodies that would "freak out" or disgust the player. These design processes are discussed uncritically, with developers revealing their assumptions about both the "feminine ideal" and what aspects of monstrosity would be the most unsettling for players. Player commentary largely discusses the monsters in terms of strategies to beat them or complaints about their difficulty, but there are also lengthy discussions about their design. Specifically, these discussions involve either commentary about how horrified they were when they encountered that monster or inappropriate and misogynistic jokes about having sexual intercourse with that monster. In this presentation, I will go through some examples of player and developer discourse regarding female monstrosity in these games which, together with some discussion of the monsters themselves and how their design remediates harmful tropes and stereotypes, will demonstrate how textual analysis and internet research can be brought together to unpack the ways that 
monstrosity is intertwined with questions of representation and misogyny in games, game design, and gaming culture.

\section{References}

Braidotti, R. (2011). Nomadic subjects: Embodiment and sexual difference in contemporary feminist theory. Second edition. Columbia University Press.

Caputi, J. (2004). Goddesses and monsters: Women, myth, power, and popular culture. University of Wisconsin Press.

Consalvo, M. (2012). Confronting toxic gamer culture: A challenge for feminist game studies scholars. Ada: A Journal of Gender, New Media, and Technology, 1.

Cote, A. C. (2020). Gaming sexism: Gender and identity in the era of casual video games. New York University Press.

Creed, B. (1993). The monstrous-feminine: Film, feminism, psychoanalysis. Routledge.

de Beauvoir, S. (1949/2011). The second sex (C. Borde \& S. Malovany-Chevallier, Trans.). Vintage. (Original work published 1949).

Harrington, E. (2018). Women, monstrosity and horror film: Gynaehorror. Routledge.

Ivory, J. (2006). Still a man's game: Gender representation in online reviews of video games. Mass Communication and Society, 9, 103-114.

Jenson, J., \& de Castell, S. (2013). Tipping points: Marginality, misogyny and video games. Journal of Curriculum Theorizing, 29(2), 72-85.

Kendrick, S. (2015). Misogyny and gaming: The maintenance of a male-gendered gamer culture. Master's thesis, University of Waterloo.

Kocurek, C. (2015). Who hearkens to the monster's scream? Death, violence and the veil of the monstrous in video games. Visual Studies, 30(1), 79-89.

Kristeva, J. (1982). Powers of horror: An essay on abjection. (L. S. Roudiez, Trans.). Columbia University Press.

Salter, A., \& Blodgett, B. (2012). Hypermasculinity \& dickwolves: The contentious role of women in the new gaming public. Journal of Broadcasting and Electronic Media, $56,401-416$.

Sobchack, V. (2000). Revenge of The Leech Woman: On the dread of aging in a lowbudget horror film. In K. Gelder (Ed.), The horror reader (pp. 336-348).

Routledge.

Stang, S. (2018). Shrieking, biting, and licking: The monstrous-feminine and abject female monsters in video games. Press Start, 4(2), 18-34. 
Stang, S. (2019). The broodmother as monstrous-feminine: Abject maternity in video games. Nordlit, 42: Manufacturing Monsters, 233-256.

Stang, S., \& Trammell, A. (2019). The ludic bestiary: Misogynistic tropes of female monstrosity in Dungeons \& Dragons. Games \& Culture, 15(6), 730-747.

Vossen, E. (2018). On the cultural inaccessibility of gaming: Invading, creating, and reclaiming the cultural clubhouse. Dissertation, University of Waterloo.

Williams, D., Martins, N., Consalvo, M., \& Ivory, J. (2009). The virtual census:

Representations of gender, race and age in video games. New Media and Society, 11(5), 815-834. 